\title{
Was Trump Right or Wrong on China? Biden's Answer Will Shape the Future
}

\begin{abstract}
Even though Washington now agrees that the policies of the Trump Administration were a failure, a consensus has emerged that Trump was right to confront China. But after four years of worsening US-China relations under the Trump Administration, the Biden administration needs to seriously rethink Washington's approach to Beijing.
\end{abstract}

The most important question that US President Joe Biden's administration needs to ask in formulating its China policy is a simple one: was Donald Trump right or wrong on China? Right now, the overwhelming consensus in Washington is that even if he was wrong on everything else, Trump was right on China. Indeed, the only Trump policy that enjoyed bipartisan consensus was his China policy, with senior Democrats such as Nancy Pelosi and Chuck Schumer praising the president on China. There is therefore a real danger that the Biden administration will retain many elements of Trump's policies toward China. If so, America is heading toward a disaster.

The goal of this essay is a simple one: to suggest that the Biden administration should first stop and do a cool, dispassionate analysis of US-China relations and then work out a coherent, credible, and comprehensive long-term strategy toward Beijing. Currently, America lacks a strategy. Henry Kissinger confirmed this to me personally. The absence of dispassionate analysis and cool strategic calculation has effectively meant that American policy toward China has swung from one delusion to another; from the delusion of the Obama/Clinton era that American engagement would transform China into a liberal democracy to the Trump/Pompeo delusion that American pressure on China would lead to the collapse of the Chinese Communist Party (CCP). In swinging from one extreme to another, without stopping at the middle path of realism, American policy toward China is headed for failure.

Yes, the Trump administration was "right" in one sense. Chinese foreign policy had become very assertive, even arrogant, after the Global Financial Crisis of 2008, when the West looked weak. Resentment toward China, including among the key constituency of US business, had been building up in the American body politic. Hence, when the Trump administration lashed out at China, it had a healthy cathartic

Originally published in Global Asia, Mar 2021

(C) The Author(s) 2022

K. Mahbubani, The Asian 21st Century, China and Globalization,

https://doi.org/10.1007/978-981-16-6811-1_7 
effect. China would have also noticed that no major American voices spoke up for China when the Trump administration unleashed its anti-China frenzy.

\section{Acknowledging a Harsh Reality}

With that catharsis over, reason must return to American policymaking. What exactly did Trump accomplish with China? Did his administration's policies raise America's standing in the world, weaken China significantly, and lead to the progressive isolation of China from the vast majority of countries? The answer to all three questions is a resounding no. The reality is that the Trump administration's policies on China damaged America's standing, did no real harm to China, and did not arrest China's growing trade and economic links with the rest of the world. Therefore, the thesis of this article is very simple: If the Biden administration continues the Trump administration's policies on China, it will only result in a weakened America, a strengthened China, and a world where far more countries will have more substantive ties with China than with America.

There's a simple reason why Trump's policies on China failed. They were not based on a realistic assessment of the adversary that America was dealing with. So, here's a simple and easy step the Biden administration can take. There are six billion people living outside America and China. If America were to take the sensible step of showing a "decent respect for the opinions of mankind," what would it learn from the perceptions of other countries toward China?

First, none would agree with the Trump administration's belief that the CCP will disappear. Instead, they would agree with the considered assessment of the Harvard Kennedy School that support for the CCP among the 1.4 billion Chinese grew from $86.1 \%$ in 2003 to $93.1 \%$ in 2016 . Second, more importantly, none see China as an exporter of communism to undermine democracy. Many Americans blithely claim that the CCP represents a threat to American democracy. So why don't the world's two largest democracies, India or Indonesia, or even the European democracies, see the CCP as a threat to their democracies? The biggest mistake in geopolitical calculations is to allow ideology to triumph over realistic analysis. Third, most serious leaders around the world see Xi Jinping as a capable, competent, and constructive leader. He may be close to exercising absolute power at home, however, he is capable of making compromises abroad (as with the Europeans on the ChinaEU investment deal and with India on the border agreement). The demonization of $\mathrm{Xi}$, particularly in the Anglo-Saxon media, has been damaging because it will lead Americans to underestimate him. The undeniable reality is that American leaders are dealing with a thoughtful and strategic leader who is making careful long-term calculations. In contrast, the Trump administration was engaged in grandstanding that neither harmed China nor benefited America. Significantly, even though Trump was praised in America for bashing China, no major country supported his policies toward China. They could see these policies heading toward failure. 
If this analysis is correct (and the facts prove that it is), the first critical step that the Biden administration needs to take is to acknowledge that Trump failed on China. Given the toxic anti-China political environment in Washington, it may not be wise to say this publicly. However, internally, the Biden administration must reach a considered consensus that Trump failed on China. With that consensus in hand, the Biden administration should chart an alternative path toward Beijing. Such an alternative path can be taken with five steps.

The first step is to press the "pause" button on the US-China geopolitical contest. Why? Two reasons. The whole world would cheer this "pause" because most countries want to focus first on fighting immediate challenges, such as Covid-19. Also, this "pause" would give the Biden administration time to reverse policies that haven't worked, for example, Trump's tariffs and export restrictions. The goal of those was clearly to weaken China's economy. And was it weakened? The data says no. Here's one key statistic on which US policymakers should reflect: In 2009, the size of China's retail goods market was USD 1.8 trillion while that of America was USD 4 trillion, more than double. By 2019 (after three years of Trump's trade war), the size of China's market was USD 6 trillion, more than tripling, while that of America only rose to USD 5.5 trillion, an increase of less than 1.5 times. On this trade war, Fareed Zakaria has observed that "The Biden campaign described Trump's trade war with China as 'an unmitigated disaster' that cost Americans money and jobs. When Biden was asked in an August interview whether he would keep Trump's tariffs, he answered 'no' and offered a wholesale critique of Trump's China policies. But none of that is being reversed. It's all 'under review." Biden was right in saying the trade war was a disaster. Hence, the rational response is to stop it.

The second step, during this "pause" period, is to do a realistic assessment of which actions by Trump may have inadvertently strengthened Xi and China. The "Longer Telegram," an anonymous essay by a former US official published earlier this year, claims that President $\mathrm{Xi}$ is accumulating detractors among Chinese elites. It argues: "The political reality is that the CCP is significantly divided on Xi's leadership and his vast ambitions. Senior party members have been greatly troubled by Xi's policy direction and angered by his endless demands for absolute loyalty. They fear for their own lives and the future livelihoods of their families." If this is true, America's strategy should be to deepen these Chinese divisions. Instead, because America lacks a strategy toward China, the Trump administration has effectively enhanced Xi's standing in China through the launch of the erratic trade war and, even more damagingly, by the detention in Canada of Meng Wanzhou, the daughter of the founder of Chinese telecom giant Huawei and the company's chief financial officer. Meng's detention has strongly reinforced the solidarity of the Chinese regime because it recalls powerful memories of China's "Century of Humiliation," when Western laws were applied on Chinese soil. Many Chinese leaders must have thought: what happens if my daughter is also detained by America?

Many Americans may balk at the idea that Meng should be released. Americans believe in the rule of law. Anyone who breaks American domestic laws should be punished. I agree. Yet Meng committed no crimes on American soil. Indeed, she didn't violate any American domestic laws. She was caught by the "extraterritorial" 
application of American laws against Iran. It's a fact that America routinely makes exemptions from such extraterritorial laws. The Biden administration should give a quiet wink to the Canadian government to release her. This would serve America's national interests. This is what geopolitical cunning is all about.

The third and most difficult step that the Biden administration will have to take is to develop a realistic understanding of the real strengths and weaknesses of its strategic adversary. Indeed, this is the most important step in any strategic competition, as emphasized by Sun Tzu in his most important maxim: "know thyself, know thy enemy; fight a hundred battles, win a hundred battles." In this context, "know thy enemy" means "know China."

In trying to understand China, the Biden administration should bear in mind a key point made by one of America's greatest strategic thinkers, George Kennan. He said that the outcome of any geopolitical contest would depend on the following: "It is rather a question of the degree to which the United States can create among the peoples of the world generally the impression of a country which knows what it wants, which is coping successfully with the problems of its internal life and with the responsibilities of a World Power, and which has a spiritual vitality capable of holding its own among the major ideological currents of the time."

If Kennan were alive today, the first question he would pose would be: which society enjoys greater "spiritual vitality," America or China? Actually, if he were alive today, he would not be able to pose this question because the very idea that a communist-run China could enjoy greater "spiritual vitality" than the world's greatest democracy is inconceivable to an American mind.

There's no question that overall, America is still today a more successful society and ahead of China in many areas. This is why my most recent book, Has China Won? begins with a fictional memo to Xi Jinping, emphasizing that China should never underestimate America. However, it would be an equally big mistake for America to underestimate China. Those Americans who believed that American engagement with China would transform China were guilty of this. Indeed, future historians will be very puzzled that a young American republic, barely 250 years old, believed that it could single-handedly transform a 4000-year-old civilization with a population four times its size. Curiously, most Americans are not even aware that this belief is somewhat arrogant.

Arrogance inhibits understanding in other ways. Few Americans are aware that for the Chinese people, especially for the bottom $50 \%$, the past 40 years have been the best in the 4000 years of Chinese history. The Stanford University psychologist, Jean Fan, has documented that "in contrast to America's stagnation, China's culture, selfconcept, and morale are being transformed at a rapid pace-mostly for the better." The overall question of whether American or Chinese society is stronger and more resilient is a massive one. It cannot be answered in a brief essay such as this one. This is why I had to write an entire book to discuss it fully. The sad reality is that most Americans just don't understand China, even though it has been around for more than four millennia. Most Americans believe that 1.4 billion Chinese people are unhappy. Hence, they cannot even conceive of the realistic possibility that the Chinese people may be swimming happily in an ocean of Chinese norms and values, 
which create both a sense of a well-ordered moral society and psychological wellbeing. By historical standards, the vast masses of Chinese people have never been better off.

\section{Long-Term Strategy}

The fourth step to take after developing a realistic understanding of China's strengths and weaknesses is to work out a comprehensive long-term strategy to manage the competition with China. This will not be easy. Some past options are not available. Containment, for example, will not be possible. More countries trade more with China than with America. Indeed, much more. Nor can America assume military superiority, especially close to China's shores. All the Pentagon war games show that American aircraft carriers and battleships are vulnerable to Chinese hypersonic missiles. Fortunately, the Mutually Assured Destruction (MAD) doctrine will prevent all-out war between America and China.

The Biden administration has been wise in reaching out to allies and friends in formulating a new China policy. Many allies and friends, including Japan, India, the UK and Australia, share American strategic concerns about the rise of Chinese power. They are worried. This is real. Yet none will join a containment policy. This is not just for economic reasons. All countries around China are asking a question that is unmentionable in American strategic circles: which economy will be bigger in a decade or two: America's or China's? Most realistic analysts expect the American economy to become number two within a decade or two. Surely, the strategic calculations of the whole world, including of America, will change when America's economy goes from being No. 1 in the world to becoming No. 2. Any serious strategic planner in America must consider this possibility. But only few brave souls dare discuss this publicly in America. It is politically taboo for any American politician to talk of this almost inevitable outcome: America could become No.2 in the world. This is another key reason why the Biden administration needs to carry out a massive strategic recalculation before proceeding full steam ahead with Trump's policies.

The fifth and final step that the Biden administration needs to take may look simple: Stop insulting China (in the way Vice President Mike Pence and Secretary of State Mike Pompeo used to do). Given the American propensity to pass judgment on other countries, this may be difficult. But the Biden administration should consider not insulting China for two reasons. First, even today, America is the only country that insults China. No other government in the world does so. In such a context, it is not China that will look isolated. America will. Second, the public insults of China feed an unconscious strain in the Western body politic that could seriously complicate Sino-American relations: the fear of the "yellow peril." This fear has surfaced from time to time, contributing to the rise of anti-Asian violence in America.

At the end of the day, what most of humanity would like to see is a rational understanding and a rational discourse between the world's two leading powers, America and China. Insults never help. One of the best definitions of a good diplomat 
is that he or she is someone who can tell you to go to hell in such a way that you feel you are going to enjoy the journey. Diplomacy has been around for several thousand years. It's the best weapon the Biden administration can use to build a new relationship with China, with the right balance of competition and cooperation.

Open Access This chapter is licensed under the terms of the Creative Commons AttributionNonCommercial-NoDerivatives 4.0 International License (http://creativecommons.org/licenses/bync-nd/4.0/), which permits any noncommercial use, sharing, distribution and reproduction in any medium or format, as long as you give appropriate credit to the original author(s) and the source, provide a link to the Creative Commons license and indicate if you modified the licensed material. You do not have permission under this license to share adapted material derived from this chapter or parts of it.

The images or other third party material in this chapter are included in the chapter's Creative Commons license, unless indicated otherwise in a credit line to the material. If material is not included in the chapter's Creative Commons license and your intended use is not permitted by statutory regulation or exceeds the permitted use, you will need to obtain permission directly from the copyright holder.

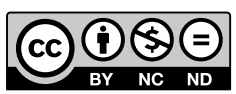

